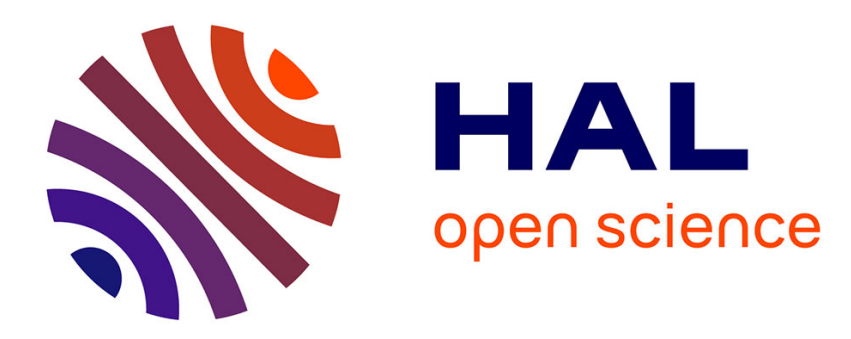

\title{
On the sensitivity of returns to seniority to the measurement of earnings
}

Arnaud Lefranc

\section{To cite this version:}

Arnaud Lefranc. On the sensitivity of returns to seniority to the measurement of earnings. International Journal of Manpower, 2003, 24 (7), pp.789 - 811. 10.1108/01437720310502131 . hal-01651776

\section{HAL Id: hal-01651776 https://hal.science/hal-01651776}

Submitted on 1 Apr 2020

HAL is a multi-disciplinary open access archive for the deposit and dissemination of scientific research documents, whether they are published or not. The documents may come from teaching and research institutions in France or abroad, or from public or private research centers.
L'archive ouverte pluridisciplinaire HAL, est destinée au dépôt et à la diffusion de documents scientifiques de niveau recherche, publiés ou non, émanant des établissements d'enseignement et de recherche français ou étrangers, des laboratoires publics ou privés. 


\title{
On the Sensitivity of Returns to Seniority to the Measurement of Earnings
}

\author{
Arnaud Lefranc*
}

June 24, 2003

\begin{abstract}
This paper examines the incidence of measurement error in wage data on the estimation of returns to seniority. Earnings surveys collect wage data through questions pertaining to earnings and hours over a given period of time (year, week) or through direct reports of hourly wages. Comparing results for different wage variables from the Panel Study of Income Dynamics (PSID), I show that estimated returns to seniority are very sensitive to the type of wage data used. Estimates based on yearly reports are typically twice as large as those using direct reports. Two sources account for this discrepancy. Firstly, the inclusion of earnings from secondary jobs and overtime in the PSID annual earnings data tends to overestimate returns to seniority. Secondly, hourly wages computed from yearly measures include important measurement errors that tend to bias coefficients upward.
\end{abstract}

JEL Classification: J310, J330, J410, C810

Keywords: Wages, Earnings, Seniority, Measurement error, Secondary jobs, Overtime.

* THEMA, Université de Cergy-Pontoise, 33 Boulevard du Port, 95011 Cergy, France; lefranc@eco.u-cergy.fr; tel : +33 1342561 71; fax : +33 134256233. 


\section{Introduction}

A number of theoretical models have suggested that wages should rise as workers accumulate job seniority, either because of an increase in specific human capital (Becker, 1964) or because of compensation deferral (Lazear, 1981) 1 Yet, after twenty years of empirical research, no consensus has emerged regarding the empirical relevance of this widely accepted hypothesis. Authors using similar data sets and related methodologies have come to opposite conclusions regarding the contribution of seniority to the dynamics of individual earnings: as an example, published estimates of returns to ten years of seniority for US workers range from a low $6.9 \%$ (Altonji and Shakotko, 1987) to as high as 28\% (Topel, 1991).

Two distinct factors are likely to explain these differences in estimates. First they may come from differences in econometric specifications used by different authors. Second, this lack of robustness may also result from the lack of reliability of the data used in these studies. This paper examines the contribution of this second source of differences in estimates by looking at the sensitivity of estimated returns to seniority to the scope and quality of earnings variables, as measured in survey data.

Differences in econometric specifications mostly arise from the use of alternative solutions to the econometric problems raised by the estimation of wage tenure profiles. Early evidence of a strong positive correlation between wages and tenure in cross-section data (Mincer and Jovanovic, 1981) have raised concern about the possible endogeneity of seniority: in the presence of unobserved heterogeneity, job mo-

\footnotetext{
${ }^{1}$ Recent papers have also suggested that the scope of specific human capital could extent beyond firm-level up to the industry level (see Neal (1995) and Parent (2000), which would first and foremost imply a positive relationship between firm seniority and wages.
} 
bility decisions are likely to induce a (positive) spurious correlation between tenure and wages as long as better jobs are more likely to last or better workers more likely to stay on their job. The first studies that addressed this issue suggested that endogeneity bias accounted for most of the cross-correlation between seniority and wages (see Abraham and Farber (1987) and Altonji and Shakotko (1987)). Yet these conclusions were questioned by Topel (1991) who demonstrated that estimators used in previous studies induced important downward biases and who offered an alternative estimation procedure.

This latter study is often considered to provide definitive evidence of a positive relationship between tenure and wage growth.2 Yet, different papers have argued that extensive measurement error and the use of partly inadequate variables might also bias estimates of returns to seniority. For instance, Altonji and Williams (1992; 1997) emphasize that estimated returns to seniority are strongly sensitive to the type of wage information used in the estimation. Their data - as well as Topel'scome from the Panel Study of Income Dynamics (PSID). Two wage variables are available in these data: the first one is computed from annual reports of hours and earnings and the second consists of self-reported hourly earnings. Altonji and Williams show that estimated returns to seniority more than double when using average hourly earnings instead of self-reported hourly earnings. This sensitivity of estimated returns to the measurement of earnings challenges the robustness of Topel (1991)'s results to the extent that these results rest entirely on the use of a

\footnotetext{
${ }^{2}$ For instance, in their 1991 survey of the empirical literature, Devine and Kiefer note: "The findings have gone full circle and beyond - the most recent results suggest that the early OLS results attributed too small a share of wage growth to tenure ... " (Devine and Kiefer (1991), quoted in Altonji and Williams (1997))
} 
specific wage variable. Furthermore, this concern is reinforced by recent studies on the reliability of survey data that have underlined the biases that might arise from the use of noisy and unreliable data. $\left.\right|^{3}$ Unfortunately Altonji and Williams do not explain this sensitivity and thus do not give much guidance regarding which variable should be used in the analysis.

The objective of this paper is to give a formal account of the different factors that contribute to this sensitivity of estimates to the measurement of earnings. Two main explanations are considered. The first is that the two wage variables might not refer to the same definition of earnings and that such differences in the scope of the two variables might account for differences in estimates. The second is that even if the scope of the two variables is the same they might be differently affected by measurement error (due to differences in the measurement protocol) and thus produce different results. This sensitivity analysis is performed using Topel (1991)'s two-step estimation procedure.

Section 2 briefly presents the econometric model and replicates Topel's estimation using two different wage variables available in recent waves of the PSID. Section ?? documents the differences in the definition of the two wage variables and analyzes their incidence on estimated returns to seniority. Section 4 evaluates the extent of measurement error in each of the two wage variables and discusses possible biases that might arise from measurement error.

\footnotetext{
${ }^{3}$ See for instance Bound et al. (1994), Rodgers et al. (1993), and Duncan et Hill (1989; 1985) for validation studies of the PSID data.
} 


\section{Methodology and replication results}

\subsection{Econometric model}

The econometric model is borrowed from Topel (1991). It assumes that earnings of individual $i$ in firm $j$ at date $t$ are given by:

$$
w_{i j t}=X_{i j t} \beta+E X P_{i t} \gamma+T E N_{i j t} \delta+\phi_{j}+\theta_{i}+\nu_{i j t}
$$

where $w_{i j t}$ denotes log hourly wage, $X_{i j t}$ is a set of observable individual characteristics (education, marital status, geographical dummies, union coverage), EXP $P_{i t}$ denotes general labor market experience, $T E N_{i j t}$ denotes tenure of individual $i$ in firm $j$ at date $t, \phi_{j}$ is an unobservable firm fixed effect, $\theta_{i}$ is an unobservable individual fixed effect, $\nu_{i j t}$ is an idiosyncratic transitory shock.$^{4}$

With endogenous job mobility, experience and seniority are likely to be correlated with individual and firm fixed effects. Hence, OLS estimates of $\gamma$ and $\delta$ will be biased. First-differencing equation 1 for individuals who stay on the same job solves the endogeneity problem but at the cost of identification: for these individuals linear increments in seniority and general experience are identically equals. 5 One can only obtain an unbiased estimate of the linear joint effect of seniority and experience on earnings, $\gamma+\delta$, by estimating the following equation:

$$
\Delta w_{i j t}=\Delta X_{i j t} \beta+\Delta E X P_{i t}(\gamma+\delta)+\Delta \nu_{i j t}
$$

\footnotetext{
${ }^{4}$ As in Topel (1991), higher order terms in experience and seniority, while included in the estimations, are omitted here to simplify the notations.

${ }^{5}$ Note that higher-order terms in seniority and experience (ignored here) are identified in the first-differenced equation.
} 
From this first-step estimation, one can subtract the total wage gain since entry in the firm $\left((\widehat{\gamma+\delta}) T E N_{i j t}\right)$ from earnings at date $t w_{i j t}$ and get an estimate of entry salary. Returns to experience can then be estimated by regressing entry salary on experience at the date of entry $I N E X P_{i j}$. Noting that $I N E X P_{i j}=E X P_{i t}-$ $T E N_{i j t}$, this amounts to estimate:

$$
\begin{aligned}
w_{i j t}-T E N_{i j t}(\widehat{\gamma+\delta}) & =X_{i j t} \beta+I N E X P \gamma+\phi_{j}+\theta_{i}+\nu_{i j t}+e_{i j t} \\
\text { with } e_{i j t} & =T E N_{i j t}[(\gamma+\delta)-(\widehat{\gamma+\delta})]
\end{aligned}
$$

As discussed in Topel (1991), the second-step estimate of $\gamma$ provides an upper bound on returns to experience, to the extent that initial experience is positively correlated to unobserved firm fixed effects ${ }^{6}$ Subtracting this estimate $\widehat{\gamma}$ from the joint effect of seniority and experience, $(\widehat{\gamma+\delta})$, one gets a lower bound on returns to seniority.

Finally, second-step standard errors estimates must account for sampling error in the first-step estimates, as suggested in Murphy and Topel (1985).

\section{$2.2 \quad$ Data}

The data used in Topel's estimation as well as in our replication come from the Panel Study of Income Dynamics.

Topel restricts his sample to white male heads of households aged 18 to 60 at the survey date. Workers from the poverty sub-sample of the PSID are excluded from

\footnotetext{
${ }^{6}$ This prediction is supported by matching models where workers locate more adequate job matches through a time-consuming process. See for instance Jovanovic (1979).
} 
his regressions as well as governmental, agricultural or self-employed workers and individuals from Alaska and Hawaii. The same restrictions apply in our sample.

Job tenure recorded in the PSID is strongly error-ridden. In many cases, individuals staying on the same job declare inconsistent year-to-year tenure increases. As is well known, this form of measurement error will especially affect first-step estimates of on the job wage growth, to the extent that these estimates are based on firstdifferenced tenure data. In order to reduce the consequences of measurement error in tenure on estimates, I correct original self-reported tenure data for measurement errors to insure cross-year consistency of tenure reports within a given job, following Topel (1991) ${ }^{7}$

In Topel's study, the wage data refer to Average hourly earnings, obtained by dividing previous year labor earnings by previous year hours of work. This is the only wage variable available over Topel's estimation period (waves 1968 to 1983). Starting with wave 1979, direct reports of current hourly wage rate are also available in the PSID in a variable labelled "Hourly wage rate on main job". In this paper I use waves 1979 to 1992 of the PSID and alternatively estimate returns to seniority using both wage variables. In each case, aggregate wage growth is controlled for by deflating individual hourly wages by a real wage index and the general consumer

\footnotetext{
${ }^{7}$ Original tenure data exhibit many inconsistencies. In numerous cases, year-to-year tenure variation for individuals staying on the same job fail to equal one. Whenever tenure reports are consistent before and after a given inconsistency, I correct misreported tenure by trend extrapolation. Otherwise, for jobs starting during the period of observation 1968-1992, I increment tenure by one in each wave, starting from the job's first year. For jobs for which no cross-year consistent report of tenure was available and not starting over the period 1968-1992, initial tenure is set equal to the first observed tenure or to the mid point of the first bracketed tenure interval observed and then incremented by one for each subsequent year. Note that for jobs not starting in the sample and for which the first observation is bracketed, Topel assigns first observation tenure based on maximum recorded tenure. Contrary to Topel 's assignment procedure, mine does not induce any systematic bias in the measurement of tenure. Yet, to the extent that my estimates are based on post-1979 data, this difference in recoding is likely to be of minor influence.
} 
price index, as in Topel (1991) ${ }^{8}$

Finally, since one of the wage variables refers to earnings during the previous year, our sample excludes observations with less than one year of seniority at the date of interview and ignores individuals who might have held more than one main job over the previous year $9^{9}$

Other dependent variables include general labor market experience (age-years of education-6), years of education dummies, union coverage, marital status and state dummies. Summary statistics are given in table 4 .

\subsection{Replication results}

Our main replication results are presented in table 1. Column 1 reproduces Topel (1991)'s findings. Columns 2 and 3 provide estimates of the two-step model using waves 1979 to 1992 of the PSID. The estimated effects of seniority on earnings are also presented in figure 1, panel A.

Estimates in columns 1 and 2 use Average hourly earnings as a dependent variable. Our results (column 2) closely replicate those in Topel (1991) (column 1). The linear joint effect of seniority and experience on wage growth is slightly lower in our replicated sample (.1136 versus .1258 in Topel's study) while the effect of seniority alone is slightly higher in our sample (.0604 versus .0545). Higher order terms in seniority are very similar between the two estimations. As a result, our estimations

\footnotetext{
${ }^{8}$ The real wage index used here is the aggregate hourly real earnings index published by the BLS for all private non-agricultural workers (BLS series EES00500049).

${ }^{9}$ It could be argued that excluding short duration jobs may lead to biased estimates of returns to seniority. In particular, if these jobs exhibit slower wage growth, this sample selection rule may produce upward biased estimates. In fact, evidence provided in Topel (1991) indicate the absence of such selection bias. Furthermore, even if such selection bias was present, this would not challenge the conclusions obtained below, to the extent that this selection bias applies indifferently to the different wage measures used in this paper.
} 
predict a slightly higher effect of seniority on earnings but the order of magnitude is very similar between the two estimations: the cumulative effect of seniority on log wages is .201 in our estimation versus .1793 in Topel's estimations after 5 years of seniority, .275 versus .2459 after 10 years and .310 vs .2832 after 15 years. Furthermore, the aforementioned differences are not statistically significant. In summary, comparison of columns 1 and 2 suggests that Topel's finding of a high return to job seniority is very robust to a change in the estimation period.

Estimates in column 3 use self-reported hourly wage as a dependent variable ("Hourly wage rate on main job"). Using this alternative measure of earnings has two noticeable effects. First it reduces the linear joint effect of seniority and experience on on-the-job wage growth estimated in the first step: this effect decreases from .1136 to .0743 . Second it reduces the magnitude of the coefficients of higher order terms in tenure. On the other hand, estimated coefficients on the total experience variables are not strongly affected. As a result, predicted effects of seniority on earnings based on self-reported hourly wages are about 55 to $60 \%$ lower than those based on average hourly earnings. This holds both for Topel's estimates and estimates in column 2. Finally, wage-seniority profiles are more concave when estimated using self-reported hourly wages and appear to level up after 10 years of seniority. One should note that similar sample restrictions apply to models in column 2 and 3. Differences in the number of observations stems from the fact that a small fraction of individuals in the sample who answer questions about yearly earnings and hours but do not answer questions about current hourly earnings. As we will see, this difference in the sample do not account for these results.

These results emphasize the sensitivity of estimated returns to seniority to the 
earnings variable used in the estimation and corroborate earlier findings by Altonji and Williams $(1992 ; 1997)$. Yet, as noted in the introduction, these two authors fail to fully account for this sensitivity ${ }^{10}$ In particular, they assume that the two variables refer to the same definition of earnings and do not question the incidence of differences in the data collection protocol from which each variable is produced. As we will see, since the two wage variables come from distinct sources in the PSID questionnaire, differences in the definition of these variables account for part of these differences in estimates.

\section{Sensitivity of estimates to the scope of the wage variables}

\subsection{Definitions of the wage variables}

Table 2 provides complete definitions of the earnings and hours data available in the different waves of the PSID.

Average hourly earnings The first measure of hourly wage available in the PSID is denoted by "Average hourly earnings". As stated in the PSID documentation,

\footnotetext{
${ }^{10}$ Altonji and Williams suggest two explanations. In their 1992 paper they argue that average hourly earnings might overestimate total wage growth for job movers to the extent that for these individuals previous year earnings mix wages on the current and previous jobs. While this explanation applies to their estimation procedure, it won' $t$ explain differences in estimates found here which are based on job stayers with more than one year of seniority. The second explanation discussed in Altonji and Williams (1997) is that differences in the timing of the average hourly wage variable and the tenure variable might lead to overestimate the returns to seniority in columns 1 and 2. Altonji and Williams argue that average hourly wages at time $t$, based on previous year earnings and hours, are implicitly regressed on tenure at time $t+1$. i.e. at the survey date. If this were true, consistent estimates of returns to the ten first years of seniority should be measured as the effect of an increase from 1 to 11 years of seniority. If measured returns to seniority are strongly concave, this will be lower than the effect of an increase form 0 to 10. (See Altonji and Williams (1997) section 5). Yet, as shown in their 1997 paper, correcting for timing differences in the tenure and wage variables while reducing estimated returns to seniority does not bridge the gap between estimates based on average hourly earnings and those based on self-reported hourly wage.
} 
this variable is not self-reported but is constructed as the ratio of previous (calendar) year income from labor ("Total labor income in prior year") divided by previous year hours of work for money ("Annual hours worked in prior year"). This variable is available for all waves of the PSID between 1968 and 1992. It corresponds to the wage variable used by Topel.

Definition of "Total labor income in prior year" indicates that this variable is inclusive of all sources of labor income. Aside from regular earnings on the main job, this variable also includes income from overtime and bonuses on the main job, income from secondary job(s) as well as supplementary income derived from gardening and rooming.

"Annual hours worked in prior year" includes all hours worked for money, including hours worked on secondary jobs and hours worked overtime on the main job. Depending on the wave, total hours are either directly reported or computed from declarations of usual hours worked on primary or secondary jobs and the number of weeks worked on each job.

Hourly wage rate on main job The second hourly wage variable available in the data corresponds to the "Hourly wage rate on main job". It is available since 1970 for workers paid by the hour and since 1978 for salaried workers. Until 1992, the former are directly asked to report their hourly rate, while the latter are asked to report their salary which is then divided by hours worked over the relevant time period 11 Until 1979 values for this variable are top-coded at a value of $\$ 9.98$ per

\footnotetext{
${ }^{11}$ The PSID documentation is somewhat unclear regarding the adjustment for hours worked. Part of the documentation mentions that "if salary is given as an annual figure, it is divided by 2000 hours per year; if weekly, by 40 hours per week". Enquiry with the PSID staff indicated that, in the data, salaries were adjusted for reported usual working time over the relevant period : if
} 
hour and are top-coded at a value of $\$ 99.98$ per hour afterwards. This explains why estimations in the previous section start in 1979.

One should note that this variable explicitly measures usual earnings on the main job held at the time of the interview and for which information on seniority is collected. As noted above, this is not the case with the wage variable used in Topel, which includes labor incomes earned on all jobs held by the respondent.

Other measures of hourly wage Several other wage variables are available in recent waves of the panel that help narrow the scope of the first wage variable and make it comparable to the scope of the self-reported hourly wage rate.

Starting in 1977, the PSID records specific information on hourly wage rates for overtime on the main job as well as wage rates on secondary jobs. Data on supplementary labor income and main job bonuses are also collected. Furthermore, after the 18th wave of the panel, available data also include usual weekly hours on main and extra jobs, number of weeks worked on main and extra jobs and total hours worked over-time. From this information, it is possible to compute several alternative measures of individual hourly wage.

Subtracting supplementary labor income from gardening and rooming from total labor earnings in previous year, and dividing by total hours worked on main and secondary jobs, one can compute the Average hourly wage on all jobs.

Subtracting income (respectively hours) earned (respectively worked) on all secondary jobs from earnings (respectively hours) on all jobs, one can compute the as an annual figure, it is divided usual hours per week times the number of weeks worked on main job. 
Average hourly wage on main job. Note that for each reported extra job, annual hours worked on that extra job are computed as the number of weeks worked on that extra job times average hours worked per week on that extra job; annual income from that extra job is obtained by multiplying total hours on that job by hourly wage rate on that extra job.

Lastly, subtracting income from bonuses and overtime from the numerator and hours worked overtime from the denominator, one can compute the Average hourly wage on main job excluding overtime ${ }^{12}$

\subsection{Incidence on estimates}

From a theoretical standpoint, two arguments suggest that excluding some of the components of earnings and hours presented in the above section will provide a measure of hourly wage more adequate to the estimation of returns to seniority. Firstly, while theoretical explanations of the effect of seniority on earnings posit that seniority in one firm will increase earnings in this firm, they have no implications for earnings outside the firm. In particular, earnings from secondary jobs and supplementary labor income should be irrelevant when evaluating the extent of specific human capital accumulation or compensation deferral within a single firm. This suggests that earnings from secondary jobs should not be included in the estimation of the wage-tenure relationship. Secondly, most theoretical accounts imply that earnings will rise with seniority for given levels of work effort and intensity. To put it differently, both the human capital and the compensation contract approaches

\footnotetext{
${ }^{12}$ In our samples, some individuals reporting strictly positive hours worked overtime do not report the amount of earnings derived from these overtime hours. In these cases, we could not correct for earnings and hours from overtime.
} 
imply that base salary should rise with job seniority. Consequently, the fact that earnings may increase with seniority due to a rise in individual work intensity or effort will not be relevant when assessing the extent of specific human capital accumulation or compensation deferral. Again, this implies that earnings from overtime work or bonuses should not be included in the estimation of returns to seniority since they compensate for longer and harder working time.

In fact, the inclusion of earnings and hours from overtime and secondary jobs may be of little consequences for the assessment of the wage-seniority relationship as long as those earnings components are not related to job seniority. On the contrary if access to overtime or secondary-job holding are correlated with seniority on the main job, this will create a discrepancy between "Average hourly earnings "and "Hourly wage rate on main job" and might affect estimated returns to seniority. In this case excluding income earned and hours worked outside main job regular work hours from "Average hourly earnings" should make estimates based on yearly declarations consistent with those obtained from self-reported hourly wage.

Tables 1 and 3 present estimates of the two-step model based on the different hourly wage measures available for the period 1985-1992 and defined above. In both tables, samples for the period 1985-1992 are restricted to individuals for which all hourly wage measures are non-missing. All wage variables are regressed on the tenure variable obtained from the same sample wave ${ }^{13}$

In our base sample, estimates of returns to seniority for this period (columns 4

\footnotetext{
${ }^{13}$ As already mentioned in note 10 this introduces a small timing inconsistency to the extent that wage measures based on annual report refer to total hours and earnings in previous year while tenure is measured as of the survey date. Additional estimates (not shown here) indicate that this inconsistency has negligible influence on our results, compared to differences in the scope of the wage variable, discussed below.
} 
to 8 in table 1) are higher than those examined in the previous section, especially at high seniority levels. This holds for all wage variables, whether self-reported or computed from yearly declarations. Regarding their sensitivity to the variable used, returns to seniority estimated using self-reported hourly wage rates (column 8) are still $55 \%$ lower than those estimated using average hourly earnings and are also markedly lower than estimates found by Topel for the period 1968-1992. Note that differences in sample cannot contribute to differences in estimates since estimates are restricted to individuals for which all earnings and hours variables are available.

Subtracting supplementary income from labor earnings (column 5) has almost no effect on estimated returns to seniority. Subtracting income and hours on secondary jobs decreases returns to seniority based on yearly declarations: depending on the number of years of seniority estimated returns decrease by 5 to $8 \%$. Lastly, subtracting earnings from overtime and bonuses and hours worked on overtime also decreases the discrepancy between estimates based on yearly values and estimates based on self-reported hourly wages. In the end, eliminating irrelevant earnings and working time bridges $20 \%$ of the initial gap in estimates.

The impact of differences in the scope of the wage variables might seem to have a modest contribution to the overall discrepancies in estimates noted above. While this is true for the overall sample, it no longer holds if we separate our sample according to the worker's type of pay. Table 3 reproduces our sensitivity analysis on the sample of workers paid by the hour who represent about half of the sample in table 1. Two reasons suggest that these workers should be analyzed separately. First, unlike salaried workers for which Hourly wage rate on main job is computed as an average hourly wage over a reference period whose length may vary (week, 
year,..), workers paid by the hour are asked to directly report their hourly wage rate. Hence, for these workers Hourly wage rate on main job clearly comes from a different source than Average hourly earnings and is likely to provide a more accurate measure of hourly wage. Secondly, one might think that overtime and secondary jobs also contribute a higher portion of overall earnings for these workers.

Columns 1 and 2 present estimates of the two-step model over the period 19781992, using Average hourly earnings and Hourly wage rate on main job. Estimates based on Average hourly earnings are similar in magnitude, for this sub-sample, to those presented in Topel but appear more concave. As in the previous section, returns estimated using self-reported wage appear $55 \%$ lower than these estimates.

Columns 3 to 7 examine the effect of excluding non-relevant hours and earnings. Again, excluding supplementary income from annual earnings does not significantly affect estimates. Excluding income from secondary jobs appears much more consequential: estimates of returns to seniority decrease by 16 to $18 \%$ depending on the time horizon considered. This represent about 30\% of the discrepancy between columns 3 and 7. Excluding income and hours from overtime on the main job further reduces estimates by an extra $10 \%$.

This decrease of returns to seniority clearly indicates that the inclusion of overtime as well as earnings and hours from other jobs affects the estimation of returns to seniority. The effect of excluding these components for returns to seniority can be easily understood by looking at tables 4 and 5 . Table 4 provides the average value of our different wage measures for the sample of individual paid by the hour. Table 5 examines how the incidence of earnings from extra jobs and overtime varies with 
worker seniority.

It first appears from table 4 that exclusion of earnings and hours from extra jobs tend to increase measured hourly wage rate. Consequently, inclusion of extra jobs in the definition of average hourly earnings lead to underestimate hourly wage on the main job. This bias arises from the fact that hourly earnings on extra jobs tend to be lower than earnings from main jobs : table 5 indicates that wages earned on extra-jobs are on average .09 log points lower than wages earned on main jobs. Furthermore, extra jobs holdings and hours worked on extra-jobs tend to decrease with job-seniority : among workers paid by the hours, $16 \%$ of workers with one or two years of seniority report extra jobs against only $6 \%$ for workers with more than 10 years of seniority. This implies that the downward bias on hourly wage rate, when using extra jobs earnings and hours, will be more pronounced for low seniority workers, leading us to overestimate the effect of seniority on the wage earned on the main job.

A reverse argument can explain that hourly earnings including overtime will rise more with seniority than the hourly wage rate for the regular work time. Indeed, table 4 indicates that excluding earnings and hours from overtime lead to a fall in measured hourly earnings. As evidenced in table 5 this arises from the fact that overtime hours are usually paid higher compensation than regular hours. Furthermore, it also appears from table 5 that the number of hours worked overtime increases with job seniority. Hence including earnings and hours from overtime will again lead to overestimate the effect of seniority on the base compensation.

Overall excluding non-relevant hours and earnings now bridges about $50 \%$ of the 
initial gap in estimates for workers paid by the hour. This indicates that - at least for half of our sample- estimation of the two-step model based on irrelevant wage information leads previous published results to overestimate returns to seniority by at least $25 \%$.

\section{Incidence and consequences of measurement}

\section{errors}

While the previous section shows that, for workers paid by the hour, earnings and hours outside the main job exaggerate the effect of seniority on earnings, there still remains significant differences between estimates based on yearly declarations and those based on direct reports of hourly wage, even when excluding non relevant earnings and hours. Other factors are hence likely to contribute to this difference in estimates and it is not clear, at this point, which estimates should be favored.

Further insight can be gained by examining the reliability of the different wage variables used in the estimation. A number of studies have underlined that survey data measures of earnings and hours incorporate important measurement errors ${ }^{14}$ These errors are likely to bias econometric estimations. Finally, as suggested in Rodgers, Brown and Duncan (1993), the extent of measurement errors is likely to vary considerably with the data collection protocol used in the survey.

The objective of this section is to assess the reliability of the different wage variables used in the estimation and to analyze the econometric biases that might arise from measurement errors.

\footnotetext{
${ }^{14}$ See for instance Bound et al. (1994), Duncan et Hill (1989; 1985) and Bound and Krueger (1991).
} 


\subsection{Methodology}

Data quality is usually assessed using the so-called reliability ratio. If we assume that variable $X$ measures the underlying variable $X^{*}$ subject to random measurement error $\varepsilon$, the reliability ratio for $X$ is defined as

$$
\lambda=\frac{\operatorname{cov}\left(X, X^{*}\right)}{\mathrm{V}(X)}
$$

Under additive random measurement error this ratio is equal to $1-\mathrm{V}(\varepsilon) / \mathrm{V}(X)$ and varies inversely with the share of noise $(\varepsilon)$ in the total signal $(X)$.

Validation studies usually rely on the observation of the true variable $X^{*}$ to assess the quality of the survey response $X$. Yet, even if $X^{*}$ is not observable, as is the case with the PSID files, reliability ratios can still be computed if two independent errorridden measures of $X^{*}$ are available. Define $X_{1}$ and $X_{2}$, two variables measuring some underlying variable $X^{*}$ such that $X_{i}=X^{*}+\varepsilon_{i}(i=1,2)$. If $\varepsilon_{1}$ and $\varepsilon_{2}$ are independent, the reliability ratio for variable $X_{i}$ can then be computed as

$$
\lambda_{i j}=\frac{\operatorname{cov}\left(X_{i}, X_{j}\right)}{\mathrm{V}\left(X_{i}\right)}
$$

$\lambda_{i j}$ measure the reliability of variable $X_{i}$ when using variable $X_{j}$ as an independent measure of the underlying variable $X^{*}$.

Before proceeding with the estimation of reliability ratios on the data used in this study, several points are worth emphasizing. Firstly, it should be noted that equation 4 will only be valid under the assumption of classical (i.e. additive and independent) measurement error. This assumption cannot be tested here absent 
any true measure of $X^{*}$ and we will return to this problem in section 4.3 . Secondly, the identifying assumption for the reliability ratio imposes that variables $X_{i}$ and $X_{j}$ come from distinct sources. Consequently, reliability ratios for hourly wage measures based on annual declarations can only be computed from direct reports of hourly wage rate and vice versa Lastly, one should note that differences in the reliability of variables $X_{i}$ and $X_{j}$ will only arise from differences in the variance of each variable. It is nevertheless informative to provide a measure of $\lambda_{i j}$ instead of a simple comparison of the variances, to the extent that $\lambda_{i j}$ indicates what share of the measured variance corresponds to measurement errors.

\subsection{Incidence of measurement errors}

Tables 6 and 7 present correlation coefficient and reliability ratios for the different wage variables used in the estimations of section ??.

When examining the different wage variables in logs (table 6), it first appears that although the different variables are strongly correlated, the correlation is far from perfect, even amongst the set of variables built from yearly declarations. The reliability ratios for hourly wage based on yearly declarations appear significantly higher than those found in the PSID Validation Study 15 : Bound et al. (1994) (table 3) report reliability ratios around $40 \%$ for earnings per hour based on yearly declarations $\sqrt{16}$ Since their data come from a single firm where the variance in wages is lower than in the economy as a whole, the higher reliability ratios found here

\footnotetext{
${ }^{15}$ The PSID Validation Study consists in a sample of workers at a participating firm who were asked to answer parts of the original PSID questionnaires. Information on some collected items (wage, hours, tenure) were also available from firm records which enable to gauge the reliability of workers answers against (assumedly) error-free independent observations.

${ }^{16}$ The table in Bound et al. (1994) reports the noise to total variance ratio which is the complement to unity of the reliability ratio used here.
} 
should not be surprising.

Comparison of reliability ratios for the different variables also indicates that data quality is higher for self-reported Hourly wage rate on main job than for variables based on yearly declarations. For all individuals, the reliability ratio for Average hourly earnings when estimated using Hourly wage rate on main job as an alternative measure is equal to .8365 while in the reverse case, the reliability ratio for Hourly wage rate on main job is equal to .9338 .

Higher quality of the self-reported wage rate can be easily understood in the light of Bound et al.'s results: they show that while yearly earnings and hours are fairly accurately reported, taking the ratio of these two variables turns into an inaccurate measure of hourly earnings because measurement errors in each of the variables are weakly correlated while the underlying wage and hours variables are strongly correlated 17

Removing non-relevant earnings and hours from the yearly declaration decreases the reliability of hourly wage measures. Since overtime and extra-job earnings and hours are also measured with error, removing earnings and hours on other jobs, adds measurement error to the initial declarations, eventhough it makes the scope of the hourly wage variable more relevant to the estimation of returns to seniority.

Splitting the sample by type of pay first indicates that the higher reliability of self-reported measures of hourly earnings holds for both groups of workers. Secondly, it appears that the higher reliability of this measure is more important for workers

\footnotetext{
${ }^{17}$ One should also note that while earlier waves of the PSID adopt different top coding procedures for the Hourly wage on main job and the Average hourly earnings variables, waves used in this section respectively top-code hourly earnings at $\$ 99.98$ and $\$ 99.99$. Hence top-coding cannot differently affect the sample variance of either of these variables.
} 
paid by the hour (.7824 vs. .9740) then for salaried workers (.8667 vs. .9113).

Table 7 examines the wage growth data and provides a different view on the reliability of our wage data. Overall, the reliability of wage growth data is rather low: gauging average yearly wage against self-reported hourly wage and vice-versa results in reliability ratios of about $25 \%$. First-differencing error-ridden data hence appears to increase the variance of measurement error. This result was already noted in Bound et al. (1994), a study that found reliability ratios of the same order of magnitude. Again, it can be explained by the fact that hourly wage rates are much more correlated over time than measurement error in these variables.

Again, wage growth based on self-reported wages appear less error-ridden than those based on yearly averages. This is especially true for workers paid on an hourly basis: for these workers, estimated reliability ratios for self-reported wage range from .22 to .28 against .039 to .087 for yearly averages (panel D). For salaried workers, noise to signal ratios are lower and of the same order of magnitude for the different wage growth variables.

\subsection{Consequences}

Our analysis in the previous sections suggests that, at least for workers paid by the hour, Hourly wage rate on main job is a better measure of hourly wage on the main job for two reasons; first, it is less error ridden than variables based on annual declarations; second, its scope is more adequate to the analysis of whether hourly wage rate increases with seniority on a specific job.

While we saw that differences in scope account for part of the discrepancy in estimates, the existence of extensive measurement error does not, in itself, account 
for differences in estimates. Indeed, if, as we assumed in the previous section, measurement error are of the classical type (i.e. additive and not correlated to the true values) then using error-ridden data as a dependent variable will not induce any bias ${ }^{18}$

For measurement errors to explain differences in estimates, errors should either be correlated to other regressors or to true values of the relevant variable. Absent any measure of the true value of hourly wage it is unfortunately impossible to directly evaluate any of these hypotheses using our data set.

Using estimates from other studies provides interesting indications regarding the possible correlations and biases. Available results, based on the PSID Validation Study, suggests that measurement error might not be independent from the underlying wage variable. For instance, Bound et al show that, in the PSID Validation Study, hourly wage growth rates computed from yearly declarations of hours and earnings overestimate the true wage growth, suggesting that measurement errors are not of mean zero. Estimating the correlation between measurement error and true values, they also find that errors tend to be negatively correlated to true values of hourly wage growth ${ }^{19}$

In this case, if measurement errors in hourly wage growth rate were uncorrelated to other variables, then regressing hourly wage growth rate on any set of variable and a constant term would induce a positive bias in the estimation of the constant term and a negative bias in estimates of other coefficients. In the case of first-step estimates of the Topel model, this would amount to overestimate the linear effect of

\footnotetext{
${ }^{18}$ This wouldn't be true if such data were used as a regressor in which case estimates would be subject to the classical measurement error attenuation bias.

${ }^{19}$ On both points, see Bound et al (1994) table 3, p. 359.
} 
seniority and experience on wage growth and underestimate higher order terms in seniority.

This suggests that measurement errors in hourly wage growth variables measured from yearly declarations of hours and earnings would positively bias returns to seniority. While it should be clear that this discussion is only valid if results obtained in the PSID Validation Study carry over to the original PSID data, this could potentially explain part of the differences in estimates found in the previous section.

Finally, regarding biases that might arise from the use of self-reported hourly wage rates, no evidence is available from validation studies regarding the correlations of measurement errors to true values. One should nevertheless expect such biases to be less severe since measurement error is quantitatively less important for these variables 20

\section{Conclusion}

The research presented here emphasizes the importance of measurement issues for regression analysis based on survey data. In the context of the estimation of returns to seniority, this paper has shown that the use of inadequate and error-ridden measures of earnings can lead to serious overestimation of the returns to tenure.

Our results point to an effect of about $1 \%$ a year over the first 10 years and decreasing after ten years. These findings of a modest return to seniority using

\footnotetext{
${ }^{20}$ Rodgers, Brown and Duncan note that "[... it is plausible that hourly workers can provide more sensible (less error-ridden) answers to the direct question than can be obtained by dividing some earnings measure by some hours measure" (Rodgers, Brown and Duncan (1993), page 1217).
} 
PSID survey data corroborates recent evidence based on administrative data. ${ }^{21}$ This suggests that, while the accumulation of job-specific seniority plays a significant role in the evolution of individual wages, the returns to seniority are much lower and less persistent than the value of $2 \%$ per year suggested in Topel (1991).

From a more general perspective, our sensitivity analysis confirms that empirical analysis of wage data should devote more attention to the sensitivity of estimates to the definition of variables and to the data gathering protocol. While this conclusion was already put forward by several validation studies based on single-firm replicated samples, this also calls for a more thorough evaluation of the reliability of widely used survey data.

\footnotetext{
${ }^{21}$ For instance Bronars and Famulary (1997). Also see Abowd and Kramarz (1999) for an overview of recent estimates of returns to seniority using matched employee-employer data.
} 


\section{References}

Abowd, J. M. and Kramarz, F. (1999). The Analysis of Labor Markers Using Matched Employee-Employer Data, in D. Card and O. Ashenfelter (eds), Handbook of Labor Economics, Vol. 3B, North-Holland, Amsterdam, chapter 40, pp. 2629-2710.

Abraham, K. G. and Farber, H. S. (1987). Job Duration, Seniority and Earnings, American Economic Review 77(3): 278-297.

Altonji, J. G. and Shakotko, R. A. (1987). Do Wages Rise with Job Seniority?, The Review of Economic Studies 54: 437-459.

Altonji, J. G. and Williams, N. (1992). The Effects of Labor Market Experience, Job Seniority and Job Mobility on Wage Growth, NBER Working Paper (4133).

Altonji, J. G. and Williams, N. (1997). Do Wages Rise with Job Seniority? A Reassessment, NBER Working Paper (6010).

Becker, G. S. (1964). Human Capital : A Theoretical and Empirical Analysis with Special Reference to Education, Columbia University Press, New-York.

Bound, J., Brown, C., Duncan, G. J. and Rodgers, W. L. (1994). Evidence on the Validity of Cross-Sectional and Longitudinal Labor Market Data, Journal of Labor Economics 12(3): 345-368.

Bound, J. and Krueger, A. B. (1991). The Extent of Measurement Error in Longitudinal Earnings Data: Do Two Wrongs Make a Right?, Journal of Labor Economics 9(1): 1-24. 
Bronars, S. G. and Famulari, M. (1997). Wage, Tenure and Wage Growth Variation Within and Across Establishments, Journal of Labor Economics 15(2): 285317.

Devine, T. and Kiefer, N. (1991). Empirical Labor Economics: The Search Approach, Oxford University Press, New York.

Duncan, G. J. and Hill, D. H. (1985). An Investigation of the Extent and Consequences of Measurement Error in Labor-Economic Survey Data, Journal of Labor Economics 3(4): 508-532.

Duncan, G. J. and Hill, D. H. (1989). Assessing the Quality of Household Panel Data: The Case of the Panel Study of Income Dynamics, Journal of Business and Economic Statistics 7(4): 441-52.

Institute for Social Research (1992). A Panel Study of Income Dynamics : Procedure and Codebook - Waves I to XXV, University of Michigan, Ann Arbor, MI.

Jovanovic, B. (1979). Job Matching and the Theory of Turnover, Journal of Political Economy 87(5): 972-990.

Lazear, E. P. (1981). Agency, Earnings Profiles, Productivity, and Hours Restrictions, American Economic Review 71(4): 606-20.

Mincer, J. and Jovanovic, B. (1981). Labor Mobility and Wages, University of Chicago Press, Chicago. 
Murphy, K. M. and Topel, R. H. (1985). Estimation and Inference in Two-Step Econometric Models, Journal of Business and Economic Statistics 3(4): 37079 .

Neal, D. (1995). Industry-Specific Human Capital: Evidence from Displaced Workers, Journal of Labor Economics 13(3): 653-77.

Parent, D. (2000). Industry-Specific Capital and Wage Profile: Evidence From the NLSY and the PSID, Journal of Labor Economics 18(2): 306-323.

Rodgers, W. L., Brown, C. and Duncan, G. J. (1993). Errors in Survey Reports of Earnings, Hours Worked, and Hourly Wages, Journal of the American Statistical Association 88(424): 1208-1218.

Topel, R. (1991). Specific Capital, Mobility and Wages : Wages Rise With Seniority, Journal of Political Economy 99(1): 145-176. 
Table 1: Estimates of returns to seniority for different wage variables

\begin{tabular}{|c|c|c|c|c|c|c|c|c|}
\hline \multirow{3}{*}{$T e n+E x p$} & (1) & $(2)$ & (3) & (4) & (5) & (6) & (7) & (8) \\
\hline & 0.1258 & .1136 & .0743 & .1043 & .1058 & .1118 & .1115 & .0692 \\
\hline & $(0.0162)$ & $(.0139)$ & $(.0106)$ & $(.0223)$ & $(.0228)$ & $(.0238)$ & $(.0259)$ & $(.0167)$ \\
\hline \multirow[t]{2}{*}{$\operatorname{Ten}^{2} / 100$} & -.4592 & -.491 & -.216 & -.397 & -.390 & -.386 & -.318 & -.201 \\
\hline & $(.1080)$ & $(.0976)$ & $(.0742)$ & $(.1550)$ & $(.1583)$ & $(.1656)$ & $(.1801)$ & $(.1160)$ \\
\hline \multirow[t]{2}{*}{ Ten $^{3} / 1000$} & .1846 & .1835 & .0814 & .1149 & .1080 & .1084 & .0703 & .0656 \\
\hline & $(.0526)$ & $(.0454)$ & $(.0342)$ & $(.0738)$ & $(.0754)$ & $(.0788)$ & $(.0858)$ & $(.0552)$ \\
\hline \multirow[t]{2}{*}{ Ten $^{4} / 10000$} & -.0245 & -.022 & -.010 & -.010 & -.008 & -.008 & $-3 \mathrm{E}-3$ & $-8 \mathrm{E}-3$ \\
\hline & $(.0079)$ & $(.0065)$ & $(.0048)$ & $(.0107)$ & $(.0109)$ & $(.0114)$ & $(.0124)$ & $(.0080)$ \\
\hline \multirow[t]{2}{*}{$\operatorname{Exp}^{2} / 100$} & -.4067 & -.218 & -.230 & -.141 & -.155 & -.202 & -.254 & -.178 \\
\hline & $(.1546)$ & $(.1207)$ & $(.0920)$ & $(.1876)$ & $(.1916)$ & $(.2004)$ & $(.2180)$ & $(.1404)$ \\
\hline \multirow[t]{2}{*}{$\operatorname{Exp}^{3} / 1000$} & .0989 & .0427 & .0483 & .0230 & .0267 & .0370 & .0524 & .0348 \\
\hline & $(.0517)$ & $(.0386)$ & $(.0293)$ & $(.0597)$ & (.0609) & $(.0637)$ & $(.0693)$ & $(.0447)$ \\
\hline \multirow[t]{2}{*}{$\operatorname{Exp}^{4} / 10000$} & .0089 & $-4 \mathrm{E}-3$ & $-4 \mathrm{E}-3$ & $-2 \mathrm{E}-3$ & $-2 \mathrm{E}-3$ & $-3 \mathrm{E}-3$ & $-4 \mathrm{E}-3$ & $-3 \mathrm{E}-3$ \\
\hline & $(.0058)$ & $(.0041)$ & $(.0031)$ & $(.0063)$ & $(.0064)$ & $(.0067)$ & $(.0073)$ & $(.0047)$ \\
\hline \multirow[t]{2}{*}{ Inexp } & .0713 & .0532 & .0489 & .0418 & .0434 & .0521 & .0560 & .0396 \\
\hline & $(.0181)$ & $(.0150)$ & $(.0115)$ & $(.0236)$ & $(.0241)$ & $(.0252)$ & $(.0274)$ & $(.0177)$ \\
\hline \multirow[t]{2}{*}{ Ten } & .0545 & .0604 & .0253 & .0625 & .0624 & .0597 & .0555 & .0296 \\
\hline & $(.0079)$ & $(.0074)$ & $(.0057)$ & $(.0113)$ & $(.0116)$ & $(.0121)$ & $(.0132)$ & $(.0085)$ \\
\hline$R_{1}^{2}$ & .022 & 0.000 & 0.001 & 0.002 & 0.002 & 0.002 & 0.001 & 0.002 \\
\hline$n_{1}$ & 8683 & 9153.000 & 7928.000 & 3968.000 & 3968.000 & 3968.000 & 3968.000 & 3968.000 \\
\hline$R_{2}^{2}$ & & 0.622 & 0.620 & 0.552 & 0.562 & 0.616 & 0.632 & 0.547 \\
\hline \multirow[t]{2}{*}{$n_{2}$} & & 11429.00 & 10167.00 & 4280.000 & 4280.000 & 4280.000 & 4280.000 & 4280.000 \\
\hline & \multicolumn{8}{|c|}{ Cumulative effect of seniority on log wage } \\
\hline \multirow[t]{2}{*}{2 years } & & 0.103 & 0.043 & 0.110 & 0.110 & 0.105 & 0.099 & 0.052 \\
\hline & & $(0.012)$ & (0.009) & $(0.018)$ & $(0.018)$ & (0.019) & $(0.021)$ & $(0.013)$ \\
\hline \multirow[t]{2}{*}{5 years } & .1793 & 0.201 & 0.082 & 0.227 & 0.227 & 0.215 & 0.207 & 0.106 \\
\hline & $(.0235)$ & $(0.021)$ & $(0.017)$ & $(0.032)$ & $(0.033)$ & $(0.035)$ & $(0.038)$ & $(0.024)$ \\
\hline \multirow[t]{2}{*}{10 years } & .2459 & 0.275 & 0.109 & 0.333 & 0.333 & 0.311 & 0.304 & 0.153 \\
\hline & $(.0341)$ & $(0.029)$ & $(0.023)$ & $(0.044)$ & $(0.045)$ & $(0.047)$ & $(0.051)$ & $(0.034)$ \\
\hline \multirow[t]{2}{*}{15 years } & .2832 & 0.310 & 0.118 & 0.382 & 0.379 & 0.351 & 0.341 & 0.175 \\
\hline & $(.0411)$ & $(0.036)$ & $(0.027)$ & $(0.053)$ & $(0.055)$ & $(0.056)$ & $(0.061)$ & $(0.040)$ \\
\hline
\end{tabular}

Note - All estimates are based on the two-step model (see section 2.1. Standard errors (in parentheses) account for sampling errors in the second step estimates (INEXP,TEN and EXP).

Dependent variable and sample: column (1) Topel's estimates; column (2) Average hourly earnings, 1978-1992; column (3) Self-reported hourly wage rate on current main job, 1978-1992; column (4) Average hourly earnings, 1985-1992; column (5) Average hourly wage on all jobs, 1985-1992; column (6) Average hourly wage earned on the current main job, 1985-1992; column (7) Average hourly wage earned on the current main job excluding overtime, 1985-1992; column (8) Self-reported hourly wage rate on current main job, 1985-1992. 
Table 2: Definition and availability of earnings and hours variables in the PSID

\begin{tabular}{|c|c|}
\hline Variable and Definition & Waves \\
\hline $\begin{array}{l}\text { Average Hourly Earnings in prior year } \\
\text { The formula used for this variable's generation is as follows: Total labor income in } \\
\text { prior year / Annual hours work in prior year }\end{array}$ & $68-92$ \\
\hline $\begin{array}{l}\text { Hourly wage rate on main job } \\
\text { If individual is paid hourly: What is your hourly wage rate for your regular work } \\
\text { time? } \\
\text { If individual is salaried: How much is your salary? }\end{array}$ & $70-92$ \\
\hline $\begin{array}{l}\text { Overtime Hourly wage rate on main job } \\
\text { If salaried: About how much would you make per hour for those extra hours? } \\
\text { If paid hourly: What is your hourly wage rate for overtime? }\end{array}$ & $\begin{array}{l}70-92 \\
70-92\end{array}$ \\
\hline $\begin{array}{l}\text { Hourly wage rate on extra job } \mathbf{1} / \mathbf{2} \\
\text { About how much did you make at this extra job? }\end{array}$ & $68-92$ \\
\hline $\begin{array}{l}\text { Total Labor Income in prior year } \\
\text { The values for this variable represent the actual amount of Head's labor income in } \\
\text { whole dollars and sum the following variables: - Labor Part of Farm Income; - La- } \\
\text { bor Part of Business Income; - Head's Wages Income; - Head's Bonuses, Overtime, } \\
\text { Commissions; - Head's Income from Professional Practice or Trade; - Labor Part of } \\
\text { Market Gardening Income; - Labor Part of Roomers and Boarders Income. }\end{array}$ & $68-92$ \\
\hline $\begin{array}{l}\text { Total Wages and Salaries in prior year } \\
\text { How much did you earn altogether from wages and salaries in previous year, that is } \\
\text { before anything was deducted for taxes and other things? }\end{array}$ & $68-92$ \\
\hline $\begin{array}{l}\text { Total Amount of Overtime and Bonuses in prior year } \\
\text { How much did you earn from bonuses, overtime, tips or commissions? }\end{array}$ & $70-92$ \\
\hline $\begin{array}{l}\text { Annual Hours Worked in prior year } \\
\text { The values for this variable represent the total annual work hours on all jobs including } \\
\text { overtime. This variable is the sum of Annual Hours Worked on main job in prior year, } \\
\text { Annual Overtime Hours on main job in prior year, and Annual Hours Worked on extra } \\
\text { job(s) in prior year. }\end{array}$ & $68-92$ \\
\hline $\begin{array}{l}\text { Annual Hours Worked on main job in prior year } \\
\text { This variable was calculated from the product of Weeks worked on main job in prior } \\
\text { year } \times \text { Average hours per week on main job in prior year. }\end{array}$ & $84-92$ \\
\hline $\begin{array}{l}\text { Annual Overtime Hours on main job in prior year } \\
\text { How many hours did overtime on your main job amount to in prior year? }\end{array}$ & $84-92$ \\
\hline $\begin{array}{l}\text { Annual Hours Worked on extra job(s) in prior year } \\
\text { This variable was calculated from the product of Weeks worked on extra job } 1 / 2 \text { in } \\
\text { prior year } \times \text { Average hours per week on extra job } 1 / 2 \text { in prior year. }\end{array}$ & $84-92$ \\
\hline $\begin{array}{l}\text { Weeks worked on main job in prior year } \\
\text { How many weeks did you actually work on your main job(s) in prior year? }\end{array}$ & $68-92$ \\
\hline $\begin{array}{l}\text { Weeks worked on extra job } \mathbf{1} / \mathbf{2} \text { in prior year } \\
\text { How many weeks did you work on this extra job in prior year? }\end{array}$ & $84-92$ \\
\hline $\begin{array}{l}\text { Average hours per week on main job in prior year } \\
\text { On average, how many hours a week did you work on your main job(s) in prior year? }\end{array}$ & $68-92$ \\
\hline $\begin{array}{l}\text { Average hours per week on extra job } \mathbf{1} / \mathbf{2} \text { in prior year } \\
\text { On average, how many hours a week did you work on extra job 1/2? }\end{array}$ & $84-92$ \\
\hline
\end{tabular}


Table 3: Estimates of returns to seniority for different wage variables - workers paid by the hour

\begin{tabular}{|c|c|c|c|c|c|c|c|}
\hline \multirow{3}{*}{ Ten $+\operatorname{Exp}$} & (1) & (2) & (3) & (4) & (5) & (6) & (7) \\
\hline & .0994 & .0652 & .1084 & .1148 & .1179 & .1141 & .0623 \\
\hline & $(.0201)$ & $(.0085)$ & $(.0322)$ & $(.0326)$ & $(.0354)$ & $(.0362)$ & $(.0116)$ \\
\hline \multirow[t]{2}{*}{ Ten $^{2} / 100$} & -.576 & -.351 & -.630 & -.630 & -.563 & -.504 & -.298 \\
\hline & $(.1420)$ & $(.0594)$ & $(.2208)$ & $(.2237)$ & $(.2424)$ & $(.2483)$ & $(.0794)$ \\
\hline \multirow[t]{2}{*}{ Ten $^{3} / 1000$} & .2211 & .1316 & .2505 & .2479 & .2305 & .2046 & .1006 \\
\hline & $(.0648)$ & $(.0271)$ & $(.1058)$ & $(.1072)$ & $(.1161)$ & $(.1190)$ & $(.0380)$ \\
\hline \multirow[t]{2}{*}{ Ten $^{4} / 10000$} & -.028 & -.017 & -.033 & -.033 & -.031 & -.027 & -.012 \\
\hline & $(.0090)$ & $(.0038)$ & $(.0154)$ & $(.0156)$ & $(.0169)$ & $(.0173)$ & $(.0055)$ \\
\hline \multirow[t]{2}{*}{$\operatorname{Exp}^{2} / 100$} & -.133 & -.185 & -.174 & -.202 & -.266 & -.246 & -.193 \\
\hline & $(.1729)$ & $(.0726)$ & $(.2663)$ & $(.2698)$ & $(.2923)$ & $(.2995)$ & $(.0957)$ \\
\hline \multirow[t]{2}{*}{$\operatorname{Exp}^{3} / 1000$} & .0210 & .0492 & .0309 & .0359 & .0468 & .0361 & .0536 \\
\hline & $(.0541)$ & $(.0227)$ & $(.0828)$ & $(.0839)$ & $(.0908)$ & $(.0931)$ & $(.0298)$ \\
\hline \multirow[t]{2}{*}{$\operatorname{Exp}^{4} / 10000$} & $-1 \mathrm{E}-3$ & $-5 \mathrm{E}-3$ & $-2 \mathrm{E}-3$ & $-2 \mathrm{E}-3$ & $-3 \mathrm{E}-3$ & $-2 \mathrm{E}-3$ & $-5 \mathrm{E}-3$ \\
\hline & $(.0056)$ & $(.0024)$ & $(.0086)$ & $(.0087)$ & $(.0094)$ & $(.0096)$ & $(.0031)$ \\
\hline \multirow[t]{2}{*}{ Inexp } & .0342 & .0293 & .0375 & .0430 & .0572 & .0579 & .0278 \\
\hline & $(.0219)$ & $(.0092)$ & $(.0341)$ & $(.0346)$ & $(.0374)$ & $(.0384)$ & $(.0123)$ \\
\hline \multirow[t]{2}{*}{ Ten } & .0652 & .0358 & .0709 & .0718 & .0607 & .0562 & .0345 \\
\hline & $(.0110)$ & $(.0046)$ & $(.0160)$ & $(.0162)$ & $(.0175)$ & $(.0180)$ & $(.0058)$ \\
\hline$R_{1}^{2}$ & 0.001 & 0.003 & 0.006 & 0.007 & 0.007 & 0.006 & 0.008 \\
\hline$n_{1}$ & 3922.000 & 3846.000 & 1920.000 & 1920.000 & 1920.000 & 1920.000 & 1920.000 \\
\hline$R_{2}^{2}$ & 0.540 & 0.546 & 0.547 & 0.595 & 0.696 & 0.693 & 0.514 \\
\hline \multirow[t]{2}{*}{$n_{2}$} & 4878.000 & 4809.000 & 2099.000 & 2099.000 & 2099.000 & 2099.000 & 2099.000 \\
\hline & \multicolumn{7}{|c|}{ Cumulative effect of seniority on log wage } \\
\hline \multirow[t]{2}{*}{2 years } & 0.109 & 0.059 & 0.119 & 0.120 & 0.101 & 0.093 & 0.058 \\
\hline & $(0.018)$ & $(0.007)$ & $(0.025)$ & $(0.026)$ & $(0.028)$ & $(0.028)$ & $(0.009)$ \\
\hline \multirow[t]{2}{*}{5 years } & 0.208 & 0.107 & 0.226 & 0.230 & 0.190 & 0.178 & 0.110 \\
\hline & $(0.032)$ & $(0.014)$ & $(0.046)$ & $(0.046)$ & $(0.050)$ & $(0.051)$ & $(0.017)$ \\
\hline \multirow[t]{2}{*}{10 years } & 0.270 & 0.122 & 0.297 & 0.303 & 0.244 & 0.235 & 0.135 \\
\hline & $(0.045)$ & $(0.020)$ & $(0.064)$ & $(0.065)$ & $(0.070)$ & $(0.072)$ & $(0.025)$ \\
\hline \multirow[t]{2}{*}{15 years } & 0.288 & 0.107 & 0.324 & 0.330 & 0.266 & 0.261 & 0.126 \\
\hline & $(0.054)$ & $(0.025)$ & $(0.079)$ & $(0.079)$ & $(0.086)$ & $(0.088)$ & $(0.031)$ \\
\hline
\end{tabular}

Notes - All estimates are based on the two-step model (see section 2.1). Standard errors (in parentheses) account for sampling errors in the second step estimates (INEXP,TEN and EXP).

Dependent variable and sample: column (1) Average hourly earnings, 1978-1992; column (2) Self-reported hourly wage rate on current main job, 1978-1992; column (3) Average hourly earnings, 1985-1992; column (4) Average hourly wage on all jobs, 1985-1992; column (5) Average hourly wage earned on the current main job, 1985-1992; column (6) Average hourly wage earned on the current main job excluding overtime, 1985-1992; column (7) Selfreported hourly wage rate on current main job, 1985-1992. 
Figure 1: Cumulative effect of seniority on log hourly wage

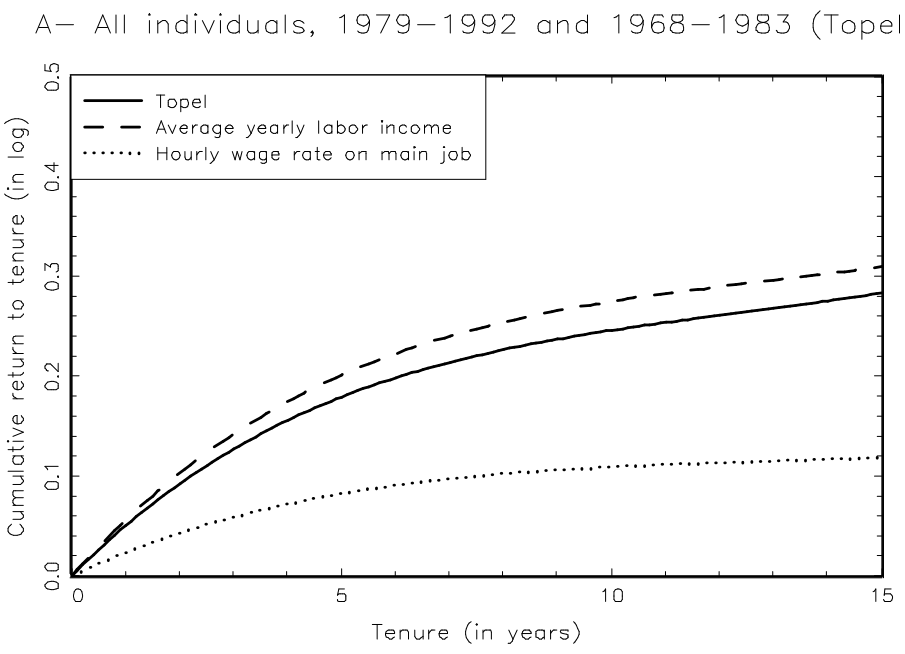

B- All individuals, 1985-1992

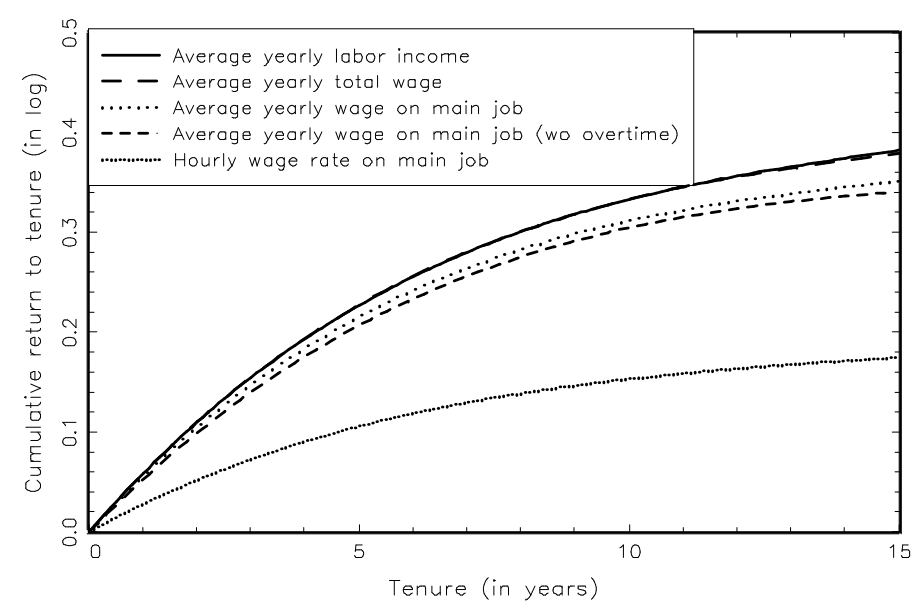

C- Workers paid by the hour, 1979-1992

D- Workers paid by the hour, 1985-1992
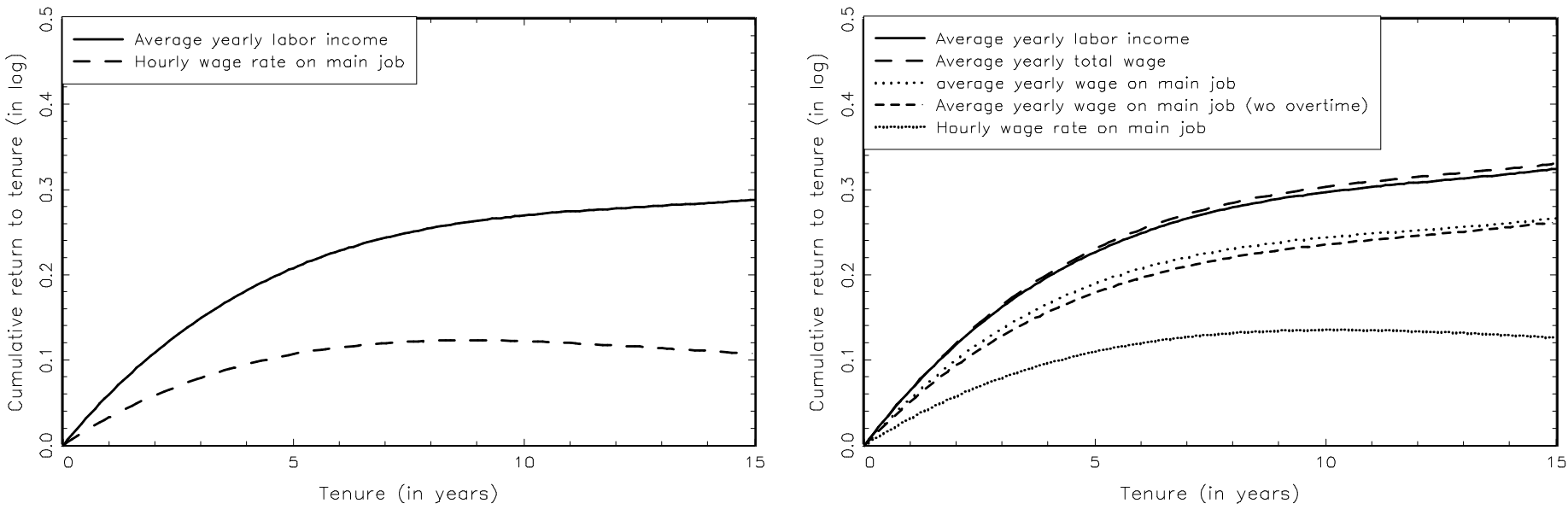
Table 4: Summary statistics

\begin{tabular}{|c|c|c|c|c|}
\hline & \multicolumn{2}{|c|}{ "All individuals } & \multicolumn{2}{|c|}{ "Workers paid by the hour } \\
\hline & 1978-1992 & 1984-1992 & 1978-1992 & 1984-1992 \\
\hline $\log$ (average hourly earnings) & $\begin{array}{c}0.5122 \\
(0.4722)\end{array}$ & $\begin{array}{c}0.5027 \\
(0.4968)\end{array}$ & $\begin{array}{c}0.3668 \\
(0.4101)\end{array}$ & $\begin{array}{c}0.3319 \\
(0.4406)\end{array}$ \\
\hline$\Delta \log$ (average hourly earnings) & $\begin{array}{c}0.0313 \\
(0.2011)\end{array}$ & $\begin{array}{c}0.0353 \\
(0.2007)\end{array}$ & $\begin{array}{c}0.0245 \\
(0.1963)\end{array}$ & $\begin{array}{c}0.0253 \\
(0.1999)\end{array}$ \\
\hline $\log$ (average hourly wage on all jobs) & & $\begin{array}{c}0.4912 \\
(0.4949)\end{array}$ & & $\begin{array}{c}0.3239 \\
(0.4411)\end{array}$ \\
\hline$\Delta \log ($ average hourly wage on all jobs) & & $\begin{array}{c}0.0349 \\
(0.2050)\end{array}$ & & $\begin{array}{c}0.0259 \\
(0.2026)\end{array}$ \\
\hline $\begin{array}{r}\log (\text { average hourly wage on main job } \\
\text { inc. overtime) }\end{array}$ & & $\begin{array}{c}0.4918 \\
(0.4977)\end{array}$ & & $\begin{array}{c}0.3247 \\
(0.4457)\end{array}$ \\
\hline $\begin{array}{r}\Delta \log \text { (average hourly wage on main job } \\
\text { inc. overtime) }\end{array}$ & & $\begin{array}{c}0.0335 \\
(0.2144)\end{array}$ & & $\begin{array}{c}0.0227 \\
(0.2193)\end{array}$ \\
\hline $\begin{array}{r}\log \text { (average hourly wage on main job } \\
\text { exc. overtime) }\end{array}$ & & $\begin{array}{c}0.4964 \\
(0.4977)\end{array}$ & & $\begin{array}{c}0.3211 \\
(0.4501)\end{array}$ \\
\hline $\begin{array}{r}\Delta \log \text { (average hourly wage on main job } \\
\text { exc. overtime) }\end{array}$ & & $\begin{array}{c}0.0309 \\
(0.2331)\end{array}$ & & $\begin{array}{c}0.0228 \\
(0.2246)\end{array}$ \\
\hline $\log ($ hourly wage rate on main job) & $\begin{array}{c}0.4719 \\
(0.4432)\end{array}$ & $\begin{array}{c}0.4374 \\
(0.4729)\end{array}$ & $\begin{array}{c}0.3068 \\
(0.3660)\end{array}$ & $\begin{array}{c}0.2514 \\
(0.3965)\end{array}$ \\
\hline$\Delta \log$ (hourly wage rate on main job) & $\begin{array}{c}0.0150 \\
(0.1429)\end{array}$ & $\begin{array}{c}0.0164 \\
(0.1500)\end{array}$ & $\begin{array}{c}0.0091 \\
(0.0821)\end{array}$ & $\begin{array}{c}0.0077 \\
(0.0726)\end{array}$ \\
\hline marital status & $\begin{array}{c}0.8839 \\
(0.3202)\end{array}$ & $\begin{array}{c}0.8845 \\
(0.3195)\end{array}$ & $\begin{array}{c}0.8856 \\
(0.3183)\end{array}$ & $\begin{array}{c}0.8870 \\
(0.3165)\end{array}$ \\
\hline education & $\begin{array}{l}13.2004 \\
(2.3915)\end{array}$ & $\begin{array}{l}13.3710 \\
(2.3274)\end{array}$ & $\begin{array}{l}11.8942 \\
(1.9375)\end{array}$ & $\begin{array}{l}12.1667 \\
(1.8486)\end{array}$ \\
\hline experience & $\begin{array}{c}18.6577 \\
(10.4839)\end{array}$ & $\begin{array}{l}18.9516 \\
(9.7515)\end{array}$ & $\begin{array}{c}18.8722 \\
(11.0312)\end{array}$ & $\begin{array}{c}19.1486 \\
(10.1544)\end{array}$ \\
\hline union coverage & $\begin{array}{c}0.2509 \\
(0.4335)\end{array}$ & $\begin{array}{c}0.2093 \\
(0.4068)\end{array}$ & $\begin{array}{c}0.4815 \\
(0.4997)\end{array}$ & $\begin{array}{c}0.3897 \\
(0.4878)\end{array}$ \\
\hline tenure & $\begin{array}{c}9.0473 \\
(8.0921)\end{array}$ & $\begin{array}{c}9.0890 \\
(7.9021)\end{array}$ & $\begin{array}{c}9.0998 \\
(8.1712)\end{array}$ & $\begin{array}{c}8.9914 \\
(7.7833)\end{array}$ \\
\hline
\end{tabular}

Notes - Standard errors in parentheses. See regression tables for numbers of observations. 


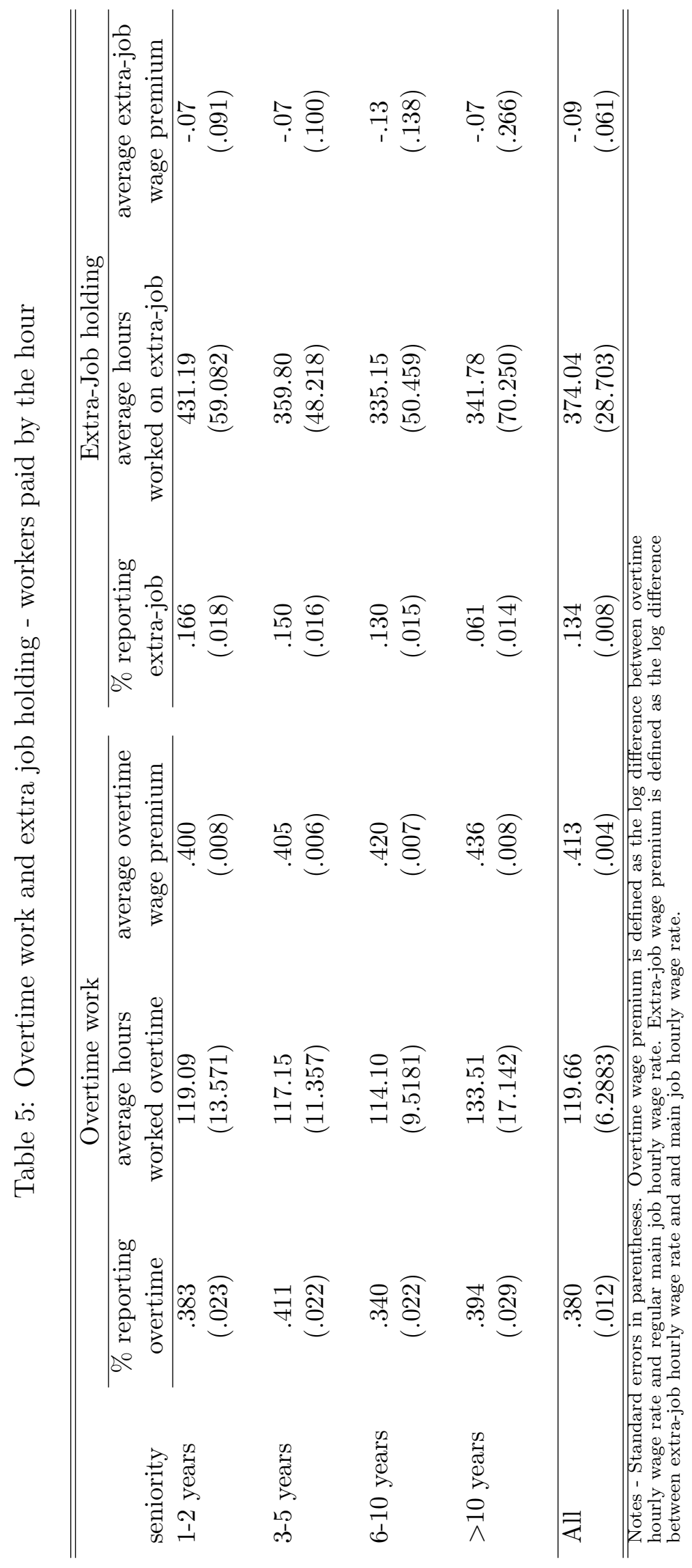


Table 6: Correlation coefficients and reliability ratios for the log wage variables 1985-1992

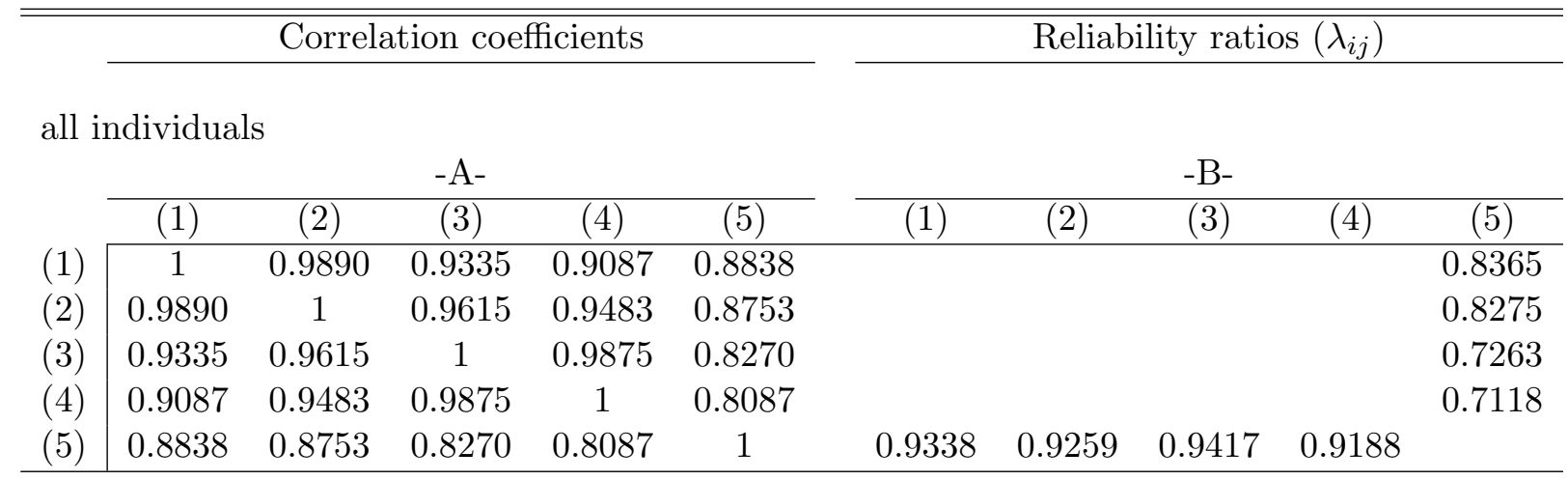

individuals paid by the hour

\begin{tabular}{|c|c|c|c|c|c|c|c|c|c|c|}
\hline & \multicolumn{5}{|c|}{$-\mathrm{C}-$} & \multicolumn{5}{|c|}{-D- } \\
\hline & (1) & (2) & (3) & (4) & (5) & (1) & (2) & (3) & (4) & (5) \\
\hline (1) & 1 & 0.9967 & 0.9571 & 0.9631 & 0.8730 & & & & & 0.7824 \\
\hline (2) & 0.9967 & 1 & 0.9685 & 0.9738 & 0.8727 & & & & & 0.7820 \\
\hline (3) & 0.9571 & 0.9685 & 1 & 0.9769 & 0.8412 & & & & & 0.7120 \\
\hline (4) & 0.9631 & 0.9738 & 0.9769 & 1 & 0.8620 & & & & & 0.7577 \\
\hline (5) & 0.8730 & 0.8727 & 0.8620 & 0.8385 & 1 & 0.9740 & 0.9739 & 0.9939 & 0.9807 & \\
\hline
\end{tabular}

individuals not paid by the hour

\begin{tabular}{|c|c|c|c|c|c|c|c|c|c|c|}
\hline & \multicolumn{5}{|c|}{-E- } & \multicolumn{5}{|c|}{$-\mathrm{F}-$} \\
\hline & $(1)$ & $(2)$ & $(3)$ & $(4)$ & $(5)$ & (1) & $(2)$ & $(3)$ & (4) & $(5)$ \\
\hline (1) & 1 & 0.9884 & 0.9730 & 0.9183 & 0.8887 & & & & & 0.8667 \\
\hline (2) & 0.9884 & 1 & 0.9886 & 0.9584 & 0.8842 & & & & & 0.8676 \\
\hline (3) & 0.9730 & 0.9886 & 1 & 0.9698 & 0.8722 & & & & & 0.8331 \\
\hline (4) & 0.9183 & 0.9584 & 0.9698 & 1 & 0.8344 & & & & & 0.7935 \\
\hline (5) & 0.8887 & 0.8842 & 0.8722 & 0.8344 & 1 & 0.9113 & 0.9011 & 0.9131 & 0.8773 & \\
\hline
\end{tabular}

Notes - (1) Average hourly earnings, 1985-1992; (2) Average hourly wage on all jobs, 1985-1992; (3) Average hourly wage earned on the current main job, 1985-1992; (4) Average hourly wage earned on the current main job excluding overtime, 1985-1992; (5) Self-reported hourly wage rate on current main job, 1985-1992.

For all the individuals in our sample, the correlation coefficient between variables (1) and (5) is .8087, the reliability ratio for variable (1) when using variable (5) as an independent measure is .8365 and the reliability ratio for variable (5) when using variable (1) as an independent measure is .9338. 
Table 7: Correlation coefficients and reliability ratios for the wage growth variables - 1985-1992

\begin{tabular}{|c|c|c|c|c|c|c|c|c|c|c|}
\hline & \multicolumn{5}{|c|}{ Correlation coefficients } & \multicolumn{5}{|c|}{ Reliability ratios $\left(\lambda_{i j}\right)$} \\
\hline \multicolumn{11}{|c|}{ all individuals } \\
\hline & & & $-\mathrm{A}-$ & & & & & $-\mathrm{B}-$ & & \\
\hline & $(1)$ & $(2)$ & $(3)$ & $(4)$ & $(5)$ & $(1)$ & $(2)$ & $(3)$ & (4) & $(5)$ \\
\hline (1) & 1 & 0.9231 & 0.7304 & 0.6536 & 0.2505 & & & & & 0.2383 \\
\hline (2) & 0.9231 & 1 & 0.8350 & 0.8122 & 0.2487 & & & & & 0.2207 \\
\hline (3) & 0.7304 & 0.8350 & 1 & 0.9543 & 0.1904 & & & & & 0.1290 \\
\hline (4) & 0.6536 & 0.8122 & 0.9543 & 1 & 0.1890 & & & & & 0.1182 \\
\hline (5) & 0.2505 & 0.2487 & 0.1904 & 0.1890 & 1 & 0.2633 & 0.2803 & 0.2810 & 0.3022 & \\
\hline
\end{tabular}

individuals paid by the hour

\begin{tabular}{|c|c|c|c|c|c|c|c|c|c|c|}
\hline & \multicolumn{5}{|c|}{$-\mathrm{C}-$} & \multicolumn{5}{|c|}{$-\mathrm{D}-$} \\
\hline & (1) & (2) & $(3)$ & (4) & (5) & (1) & (2) & (3) & (4) & (5) \\
\hline (1) & 1 & 0.9731 & 0.6656 & 0.6355 & 0.1409 & & & & & 0.0878 \\
\hline (2) & 0.9731 & 1 & 0.7584 & 0.7443 & 0.1446 & & & & & 0.0879 \\
\hline (3) & 0.6656 & 0.7584 & 1 & 0.9638 & 0.0926 & & & & & 0.0355 \\
\hline (4) & 0.6355 & 0.7443 & 0.9638 & 1 & 0.1067 & & & & & 0.0415 \\
\hline (5) & 0.1409 & 0.1446 & 0.0926 & 0.1067 & 1 & 0.2260 & 0.2378 & 0.2412 & 0.2744 & \\
\hline
\end{tabular}

individuals not paid by the hour

\begin{tabular}{|c|c|c|c|c|c|c|c|c|c|c|}
\hline & \multicolumn{5}{|c|}{$-E-$} & \multicolumn{5}{|c|}{$-\mathrm{F}-$} \\
\hline & (1) & $(2)$ & $(3)$ & $(4)$ & $(5)$ & (1) & $(2)$ & (3) & (4) & $(5)$ \\
\hline (1) & 1 & 0.8608 & 0.8055 & 0.6044 & 0.3665 & & & & & 0.4515 \\
\hline (2) & 0.8608 & 1 & 0.9565 & 0.8595 & 0.3432 & & & & & 0.3801 \\
\hline (3) & 0.8055 & 0.9565 & 1 & 0.8881 & 0.3278 & & & & & 0.3398 \\
\hline (4) & 0.6044 & 0.8595 & 0.8881 & 1 & 0.2811 & & & & & 0.2370 \\
\hline (5) & 0.3665 & 0.3432 & 0.3278 & 0.2811 & 1 & 0.2975 & 0.3098 & 0.3163 & 0.3335 & \\
\hline
\end{tabular}

Notes - (1) Change in log Average hourly earnings, 1985-1992; (2) Change in log Average hourly wage on all jobs, 19851992; (3) Change in log Average hourly wage earned on the current main job, 1985-1992; (4) Change in log Average hourly wage earned on the current main job excluding overtime, 1985-1992; (5) Change in log Self-reported hourly wage rate on current main job, 1985-1992.

For all the individuals in our sample, the correlation coefficient between variables (1) and (5) is .189, the reliability ratio for variable (1) when using variable (5) as an independent measure is .2383 and the reliability ratio for variable (5) when using variable (1) as an independent measure is .2633. 